\title{
Expression patterns and action analysis of genes associated with inflammatory responses during rat liver regeneration
}

\author{
Heng-Yi Shao, Li-Feng Zhao, Cun-Shuan Xu
}

Heng-Yi Shao, Cun-Shuan Xu, College of Life Science, Henan Normal University, Xinxiang 453007, Henan Province, China Li-Feng Zhao, Key Laboratory for Cell Differentiation Regulation, Xinxiang 453007, Henan Province, China

Supported by the National Natural Science Foundation of China, No. 30270673

Correspondence to: Professor Cun-Shuan Xu, College of Life Science, Henan Normal University, Xinxiang 453007, Henan Province, China.xucs@x263.net

Telephone: +86-373-3326001 Fax: +86-373-3326524

Received: 2006-08-25 Accepted: 2006-10-06

\begin{abstract}
AIM: To study the relationship between inflammatory response and liver regeneration (LR) at transcriptional level.
\end{abstract}

METHODS: After partial hepatectomy (PH) of rats, the genes associated with inflammatory response were obtained according to the databases, and the gene expression changes during LR were checked by the Rat Genome 2302.0 array.

RESULTS: Two hundred and thirty-nine genes were associated with liver regeneration. The initial and total expressing gene numbers found in initiation phase (0.5-4 h after $\mathrm{PH}$ ), Go/G 1 transition (4-6 h after $\mathrm{PH}$ ), cell proliferation (6-66 $\mathrm{h}$ after $\mathrm{PH}$ ), cell differentiation and structure-function reconstruction (66-168 $\mathrm{h}$ after $\mathrm{PH})$ of liver regeneration were 107, 34, 126, 6 and 107, $92,233,145$ respectively, showing that the associated genes were mainly triggered at the beginning of liver regeneration, and worked at different phases. According to their expression similarity, these genes were classified into 5 groups: only up-regulated, predominantly up-, only down-, predominantly down-, up- and down-, involving 92, 25, 77, 14 and 31 genes, respectively. The total times of their up- and down-regulated expression were 975 and 494, respectively, demonstrating that the expressions of the majority of genes were increased, and that of a few genes were decreased. Their time relevance was classified into 13 groups, showing that the cellular physiological and biochemical activities were staggered during liver regeneration. According to gene expression patterns, they were classified into 33 types, suggesting that the activities were diverse and complex during liver regeneration.

CONCLUSION: Inflammatory response is closely associated with liver regeneration, in which 239 LRassociated genes play an important role.

(c) 2007 The WJG Press. All rights reserved.

Key words: Partial hepatectomy; Rat Genome 2302.0 array; Inflammatory response; Genes associated with liver regeneration

Shao HY, Zhao LF, Xu CS. Expression patterns and action analysis of genes associated with inflammatory responses during rat liver regeneration. World J Gastroenterol 2007; 13(3): 369-377

http://www.wjgnet.com/1007-9327/13/369.asp

\section{INTRODUCTION}

Partial hepatectomy $(\mathrm{PH})^{[1]}$, being severely harmful to the body, can cause inflammatory response ${ }^{[2]}$. Furthermore, it also activates the remaining liver cells to enter into cell cycle to replenish the lost livers, which is called liver regeneration $(\mathrm{LR})^{[3,4]}$. Generally, an inflammatory response goes through the following processes: the change of vascular permeability ${ }^{[5]}$ as a result of the tissue injury ${ }^{[6]}$, leukocytes' escape from blood vessel, activation and proliferation of target cells induced by released cytokines, elimination of foreign materials, wound repair and so on ${ }^{[6]}$. It is a defense mechanism developed during the long-term evolutionary process, being closely linked to survival of living organisms ${ }^{[7]}$.

Usually, the process of LR is classified based on the cellular physiological activities into 4 phases consisting of the initiation (0.5-4 h after $\mathrm{PH})$, the $\mathrm{G}_{0} / \mathrm{G}_{1}$ transition (4-6 $\mathrm{h}$ after $\mathrm{PH})$, the cell proliferation (6-66 $\mathrm{h}$ after $\mathrm{PH})$, the cell differentiation and structure-function reorganization (66-168 $\mathrm{h}$ after $\mathrm{PH})^{[8]}$, or divided according to time course into 4 phases including forepart $(0.5-4 \mathrm{~h}$ after $\mathrm{PH})$, prophase (6-12 h after $\mathrm{PH})$, metaphase (16-66 h after $\mathrm{PH})$, and anaphase $(72-168 \mathrm{~h} \text { after } \mathrm{PH})^{[0]}$, in which a variety of physiological and biochemical events including cell activation, de-differentiation, proliferation and its regulation, re-differentiation, reorganization of structurefunction ${ }^{[10]}$ are involved. The process is regulated by many factors including inflammation ${ }^{[11]}$. Studying the relationship between inflammatory response and liver regeneration at transcriptional level is helpful to clarify the molecular mechanism of liver regeneration ${ }^{[9,12]}$. In the current study, 
the expression changes of genes in regenerating liver were detected by Rat Genome 2302.0 array $^{[13,14]}$ containing 409 genes associated with inflammatory response. Two hundred and thirty-nine genes were found associated with liver regeneration ${ }^{[15]}$, and their expression changes, patterns and roles in LR were preliminarily analyzed.

\section{MATERIALS AND METHODS}

\section{Regenerating liver preparation}

Healthy SD rats weighing 200-250 g were obtained from the Animal Center of Henan Normal University. The rats were separated into groups at random and each group included 6 rats (Male:Female $=1: 1$ ). PH was performed according to Higgins and Anderson ${ }^{[3]}$ : the left and middle lobes of the liver were removed. Rats were killed by cervical vertebra dislocation at $0.5,1,2,4,6,8,12,24,36$, $54,66,72,120,144$ and $168 \mathrm{~h}$ after partial hepatectomy and the regenerating livers were examined at corresponding time points. The livers were rinsed three times in PBS at $4^{\circ} \mathrm{C}$. Then 100-200 $\mathrm{mg}$ liver tissues from middle parts of the right lobe, six samples of each group were gathered and mixed together to a total of 1-2 $\mathrm{g}(0.1-0.2 \mathrm{~g} \times 6)$ of liver tissue, and stored at $-80^{\circ} \mathrm{C}$. The sham-operation (SO) groups were treated the same way with partial hepatectomy ones except that the liver lobes were unremoved. The laws of animal protection of China were followed strictly.

\section{RNA isolation and purification}

Total RNA was isolated from frozen livers according to the manual of Trizol kit (Invitrogen) ${ }^{[16]}$ and then purified based on the guide of RNeasy mini kit (Qiagen) ${ }^{[17]}$. Total RNA samples were examined and exhibited a 2:1 ratio of $28 \mathrm{~S}$ to $18 \mathrm{~S}$ rRNA intensities by agarose electrophoresis $(180 \mathrm{~V}, 0.5 \mathrm{~h})$. Total RNA concentration and purity were estimated by optical density measurements at $260 / 280 \mathrm{~nm}^{[18]}$.

\section{cDNA, cRNA synthesis and purification}

As template, 1-8 $\mu \mathrm{g}$ total RNA was used for cDNA synthesis. cDNA and cRNA synthesis were proceeded according to the methods established by Affymetrix ${ }^{[13]}$. cRNA labeled with biotin was synthesized using $12 \mu \mathrm{L}$ of the above synthesized cDNA as the template, and cDNA and cRNA were purified ${ }^{[13]}$. Measurement of concentration, purity and quality of cDNA and cRNA was the same as above.

\section{CRNA fragmentation and microarray detection}

Fifteen microliters $(1 \mu \mathrm{g} / \mu \mathrm{L})$ cRNA incubated with $5 \times$ fragmentation buffer at $94^{\circ} \mathrm{C}$ for $35 \mathrm{~min}$ was digested into 35-200 bp fragments. Rat Genome 2302.0 microarray produced by Affymetrix was prehybridized, then the hybridization buffer was added at $45^{\circ} \mathrm{C}$, and spun at 60 rotations per min for $16 \mathrm{~h}$. The microarray was washed and stained by GeneChip fluidics station 450 (Affymetrix Inc., USA). The chips were scanned by GeneChip Scan 3000 (Affymetrix Inc., USA), and the signal values of gene expression were observed ${ }^{[14]}$.

\section{Microarray data analysis}

The normalized signal values, signal detections (P, A, M) and experiment/control (Ri) were obtained by quantifying and normalizing the signal values using GCOS1.2 $2^{[14]}$.

\section{Normalization of microarray data}

To minimize error in the microarray analysis, each analysis was performed three times by Rat Genome 2302.0 microarray. Result with a total ratio was maximal $\left(\mathrm{R}^{\mathrm{m}}\right)$ and that of which the average of three housekeeping genes ( $\beta$-actin, hexokinase and glyseraldehyde-3-phosphate dehydrogenase) approached $1.0\left(\mathrm{R}^{\mathrm{h}}\right)$ were taken as a reference. The modified data were generated using a correction factor $\left(\mathrm{R}^{\mathrm{m}} / \mathrm{R}^{\mathrm{h}}\right)$ multiplying the ratio of every gene in $\mathrm{R}^{\mathrm{h}}$ at each time point. To remove spurious gene expression changes resulting from errors in the microarray analysis, the gene expression profiles at $0-4 \mathrm{~h}, 6-12 \mathrm{~h}$ and 12-24 h after PH were reorganized by NAP software (normalization analysis program) according to the cell cycle progression of the regenerating hepatocytes. Data statistics and cluster analysis were done using GeneMath, GeneSpring, and Microsoft Excel software ${ }^{[14,19,20]}$.

\section{Identification of genes associated with liver regeneration}

Firstly, the nomenclature of inflammatory response was adopted from the GENEONTOLOGY database (www. geneontology.org), and than input into NCBI (www. ncbi.nlm.nih.gov) and RGD (rgd.mcw.edu) to identify the rat, mouse and human genes associated with the inflammatory response. According to maps of biological pathways embodied by GENMAPP (www.genmapp.org), KEGG (www.genome.jp/kegg/pathway.html\#amino) and BIOCARTA (www.biocarta.com/genes/index.asp), the genes associated with inflammatory response were collated. The results of this analysis were coded, and compared with the results from human and mouse studies in order to identify human and mouse genes which are different from those of rat. In comparison of these genes with the analysis output of the Rat Genome 2302.0 array, those genes that showed a greater than twofold change in expression level, regarded as meaningful expression changes ${ }^{[15]}$, were referred to as rat homologous genes or rat specific genes associated with inflammatory response. Genes that displayed reproducible results with three independent analyses with the chip and showed a greater than twofold change in expression level at least at one time point during liver regeneration with significant difference $(0.01 \leqslant P<0.05)$ or extremely significant difference $(P \leqslant$ $0.01)$ between $\mathrm{PH}$ and sham operation (SO), were referred to as associated with liver regeneration.

\section{RESULTS}

\section{Expression changes of genes associated with inflammatory response during liver regeneration}

According to the databases at NCBI, GENMAPP, KEGG, BIOCARTA and RGD, 661 genes were involved in inflammatory response, in which, 405 genes were contained in the Rat Genome 2302.0 array. Among them, the expression of 239 genes displayed meaningful changes at least at one time point after $\mathrm{PH}$, showed significant or extremely significant differences in expression when compared between $\mathrm{PH}$ and $\mathrm{SO}$, and displayed reproducible 

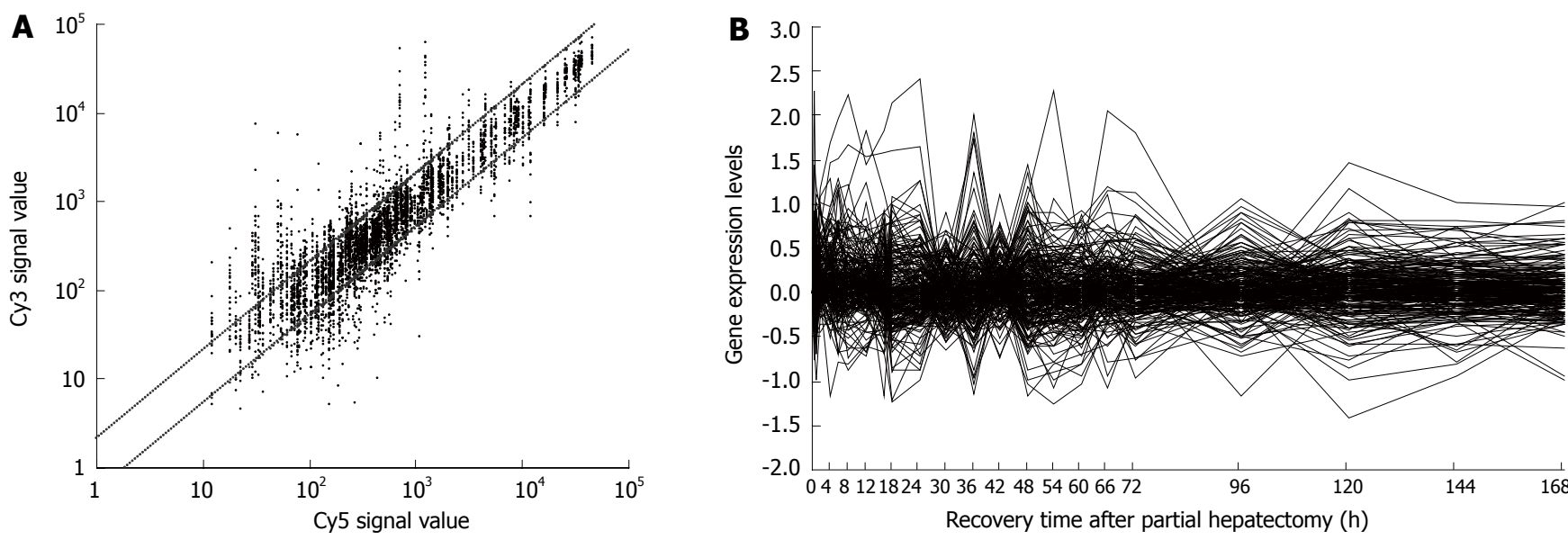

Figure 1 Expression frequency, abundance and changes of 239 inflammatory response-associated genes during rat liver regeneration. Detection data of Rat Genome 230 2.0 array were analyzed and graphed by Microsoft Excel. A: Gene expression frequency. The dots above bias represent the genes up-regulated more than two fold, and total times of up-regulation were 975; those below bias down-regulated more than two fold, and times of down-regulation were 494; and the ones between biases no-sense alteration; B: Gene expression abundance and changes. One hundred and sixty-two genes were 2-257 fold up-regulated, and 147 genes 2-25 fold down-regulated.

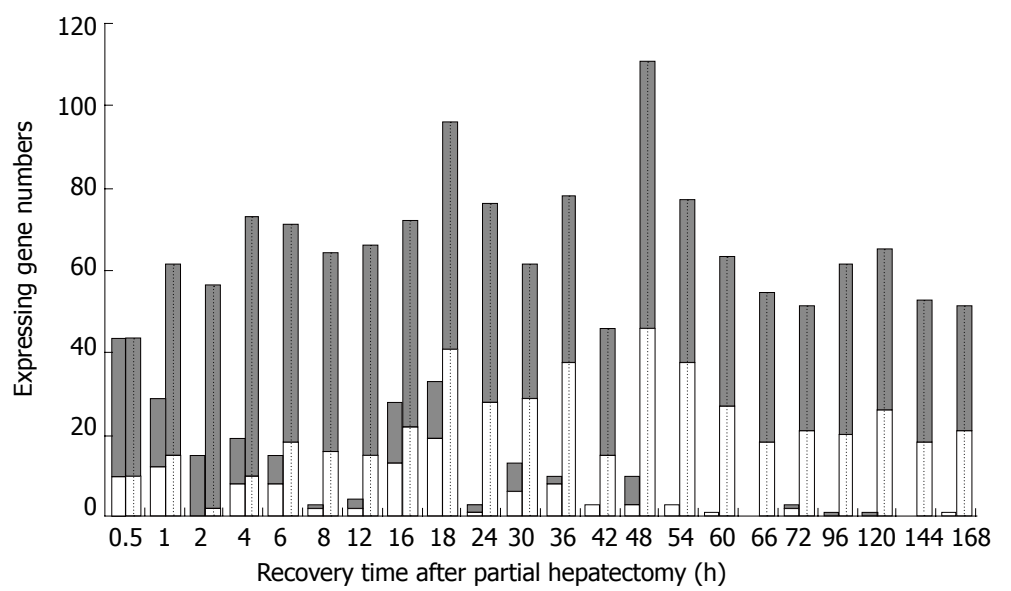

Figure 2 The initial and total expression profiles of 239 inflammatory response-associated genes at each time point of liver regeneration. Grey bars: Up-regulated gene; White bars: Down-regulated. Blank bars represent initial expressing genes, in which up-regulated genes were predominant in the forepart, and the down-regulated in the prophase and metaphase, whereas very few in the anaphase. Dotted bars represent the total expressing genes, in which some genes were up-regulated, and the others down-regulated during the whole LR. results by three detections with Rat Genome 2302.0 array, suggesting that the genes were associated with LR. Change in up-regulation ranged from 2 to 257 times higher than control, and down-regulation ranged from 2 to 25 times lower than control (Table 1). The data indicated that 92 genes were up-regulated, 77 genes down-, and 70 genes up/down-during liver regeneration. The total up- and down-regulated times were 975 and 494, respectively (Figure 1A). At the initiation phase (0.5-4 h after PH), 77 genes displayed up-regulation, 27 genes down, 3 genes up/ down; at the G0/G1 transition (4-6 h after PH), 70 genes up-regulated, 20 genes down-, and 2 genes up/down-; at the cell proliferation phase (6-66 h after $\mathrm{PH}), 102$ genes up- regulated, 84 genes down-, and 47 genes up/down-; at cell differentiation and structure-function reorganization phase (66-168 h after $\mathrm{PH}), 82$ genes up- regulated, 44 genes down-, and 19 genes up/down- (Figure 1B).

\section{Initial expression time of genes associated with inflammatory response during liver regeneration}

At each time point of liver regeneration, the numbers of initial up-, down-regulated and total up-, down-regulated genes are as followings: both 34 and 10 at $0.5 \mathrm{~h} ; 17,12$ and 47,15 at 1 h; 15, 0 and 55, 2 at 2 h; 11, 8 and 64, 10 at 4 h;
7,8 and 54, 18 at 6 h; 1, 2 and 49, 16 at 8 h; 2, 2 and 52, 15 at $12 \mathrm{~h} ; 15,13$ and 51,22 at $16 \mathrm{~h} ; 14,19$ and 56, 41 at $18 \mathrm{~h}$; 2, 1 and 49, 28 at 24 h; 7, 6 and 33, 29 at 30 h; 2, 8 and 41, 38 at 36 h; 0,3 and 31, 15 at 42 h; 7, 3 and 66, 46 at 48 h; 0,3 and 40, 38 at 54 h; 0,1 and 37, 27 at 60 h; 0,0 and 37, 18 at 66 h; 1, 2 and 31, 21 at 72 h; 1, 0 and 42, 20 at 96 h; 1, 0 and 40, 26 at 120 h; 0, 0 and 35, 18 at 144 h; 0, 1 and 31, 21 at $168 \mathrm{~h}$ (Figure 2). Generally, gene expression changes occurred during the whole liver regeneration, and the upand down-regulations were 975 and 494 times, respectively. There were predominantly initial up-regulated genes in the forepart, and the down- regulated genes in the prophase and metaphase, whereas only a few in the anaphase.

\section{Expression similarity and time relevance of genes associated with inflammatory response during liver regeneration}

Two hundred and thirty-nine genes could be characterized based on their similarity in expression as following: only up-, predominantly up-, only down-, predominantly down-, up/down-regulated, involving 92, 25, 77, 14 and 31 genes, respectively (Figure 3). According to time relevance, they were classified into 13 groups, including 0.5 and $1 \mathrm{~h}$, $2 \mathrm{~h}, 4$ and 6 h, 8 and 12, 16 and 96 h, 18 and 24 h, 30 and 42 h, 36 h, 48 h, 54 and 60 h, 66 and 72 h, 120 and 144 h, 
Table 1 Expression abundance of 239 inflammatory response-associated genes during rat liver regeneration

\begin{tabular}{|c|c|c|c|c|c|c|c|c|c|c|c|}
\hline Gene abbr. & $\begin{array}{l}\text { Associated } \\
\text { with others }\end{array}$ & $\begin{array}{l}\text { Fold } \\
\text { difference }\end{array}$ & Gene abbr. & $\begin{array}{l}\text { Associated } \\
\text { with others }\end{array}$ & $\begin{array}{l}\text { Fold } \\
\text { difference }\end{array}$ & Gene abbr. & $\begin{array}{l}\text { Associated } \\
\text { with others }\end{array}$ & $\begin{array}{l}\text { Fold } \\
\text { difference }\end{array}$ & Gene abbr. & $\begin{array}{l}\text { Associated } \\
\text { with others }\end{array}$ & $\begin{array}{l}\text { Fold } \\
\text { difference }\end{array}$ \\
\hline \multicolumn{2}{|c|}{1 Vascular reaction } & & S100a9 & & 4.9 & ${ }^{1}$ Serpine1 & & 16.7 & Ndst1 & & $0.5,2.1$ \\
\hline \multicolumn{2}{|c|}{ Adcyap1 } & 3.5 & Scube1 & $2^{\mathrm{b}}$ & 3.2 & Socs1 & & $0.5,2.4$ & Nfatc4 & & 0.5 \\
\hline \multicolumn{2}{|l|}{ Alox5 } & $0.2,2.5$ & ${ }^{1}$ Socs3 & & $0.1,2.5$ & Tgfb2 & & $0.5,2.9$ & Nfkb1 & & $0.4,2.3$ \\
\hline \multicolumn{2}{|l|}{ Alox5ap } & 4.9 & Stab1 & & 0.4 & Tnfrsf11b & & $0.3,8.7$ & Nrf1 & & $0.2,2.4$ \\
\hline \multicolumn{2}{|l|}{ Aoc3 } & 6.1 & Tac1 & & 0.2 & Tp53 & & 2.9 & Pap & & 68.6 \\
\hline \multicolumn{2}{|l|}{ Bdkrb2 } & 0.4 & Tlr2 & & 10.6 & Traf1 & & 0.4 & Pecam1 & & 3.5 \\
\hline \multicolumn{2}{|l|}{$\mathrm{Cr} 2$} & 6.0 & Tlr4 & & 0.5 & \multicolumn{3}{|c|}{3 Cell activation, proliferation and } & $\operatorname{Prd} x 5$ & & 0.5 \\
\hline \multicolumn{2}{|l|}{ Crp } & 0.5 & Vps45 & & 12.6 & differentiat & & & Prg2 & & 0.3 \\
\hline Ctsb & & 3.6 & Zap70 & & 0.4 & a Cell activ & ion & & Prg3 & & 0.2 \\
\hline Ctsc & & 0.4 & Zfp36 & & $0.1,4.6$ & Acadm & & 6.9 & Prkca & & $0.5,4.6$ \\
\hline Cysltr1 & & $0.1,2.1$ & b Cytokine & & & Adprtl1 & & 0.5 & Proc & & 0.3 \\
\hline Edg3 & & 4.0 & ${ }^{1} \mathrm{~A} 2 \mathrm{~m}$ & & $0.4,46.2$ & Ager & 4 & 0.4 & Procr & & 6.5 \\
\hline $\mathrm{F} 2$ & $2^{\mathrm{b}}$ & 0.3 & Abcb1 & & 4.6 & Ambp & & 5.1 & Prok2 & & 8.6 \\
\hline F3 & $2^{\mathrm{b}}$ & $0.1,2.0$ & Agtr1a & & 0.4 & Aox1 & & 0.3 & Pten & & 0.5 \\
\hline Ggtla1 & & 4.0 & Atrn & & 4.4 & Baat & & 0.2 & Rage & & 0.4 \\
\hline Itga1 & & 2.9 & Bcl2a1 & & $0.3,5.3$ & $\mathrm{C} 3$ & & 0.2 & Rela & $2^{a}$ & 0.5 \\
\hline Klkb1 & & 0.4 & Bdnf & & $0.4,2.6$ & C3ar1 & & $0.3,2.3$ & Ripk2 & & 0.4 \\
\hline Kng1 & & 2.1 & Casp1 & & 3.0 & $\mathrm{C} 4 \mathrm{a}$ & & 0.5 & Sele & $3^{\mathrm{b}}$ & 12.9 \\
\hline Ltb4r & $3^{\mathrm{a}}$ & $0.5,8.7$ & Ccl17 & & 0.1 & C5r1 & & $0.4,2.6$ & Slpi & & 2.1 \\
\hline Nos3 & $2^{\mathrm{b}}$ & $0.3,2.1$ & Ccl19 & & 3.9 & Casp8 & & 10.6 & Sod2 & & 5.6 \\
\hline Oldlr1 & & $0.3,6.5$ & $\mathrm{Ccl} 2$ & & 18.5 & Cd80 & & $0.3,3.0$ & Spn & & $0.2,4.0$ \\
\hline Ptafr & & 7.1 & $\mathrm{Ccl} 20$ & & 8.0 & Cd86 & & 2.6 & Tgfb1 & & 4.0 \\
\hline Ptger3 & $2^{\mathrm{a}}$ & 0.2 & $\mathrm{Ccl} 21 \mathrm{~b}$ & & $0.1,2.0$ & Chuk & & 0.3 & Tmem23 & & $0.2,4.3$ \\
\hline Ptges & & 4.5 & $\mathrm{Ccl} 24$ & & 4.0 & Cnr2 & & $0.5,2.6$ & ${ }^{1} \mathrm{Tnf}$ & & 3.2 \\
\hline Ptgs2 & & $0.1,2.1$ & $\mathrm{Ccl} 27$ & & 0.3 & Crcp & & 0.3 & Tnfaip6 & & $0.2,2.1$ \\
\hline Reg3g & & $0.3,7.5$ & Ccl4 & & $0.2,3.0$ & Crebbp & & 0.1 & Tnfrsf4 & & $0.3,2.3$ \\
\hline Spin2a & & $0.2,4.3$ & Ccl7 & & 22.6 & Csf2 & & 0.3 & Tnfsf11 & & 2.3 \\
\hline Spink5 & & 0.1 & Ccr1 & & $0.4,27.9$ & ${ }^{1} \mathrm{Ctgf}$ & & 13.9 & Tnfsf4 & & $0.2,2.3$ \\
\hline 2 Release cy & kine & & $\mathrm{Cd} 274$ & & 0.3 & Cybb & 4 & 2.5 & b Cell proli & feration & \\
\hline a Process of & lease & & Cklf1 & & 8.3 & Dusp1 & & $0.4,6.0$ & Akt1 & & 3.9 \\
\hline Abcf1 & & 2.1 & Clec7a & & 0.2 & Dysf & & $0.5,4.9$ & B7h3 & & 3.5 \\
\hline Abcf2 & & 0.4 & Ctla4 & & 0.3 & Fabp4 & & 29.9 & Bcl6 & & 8.6 \\
\hline Abcf3 & & $0.5,2.3$ & Cxcl10 & & $0.3,9.2$ & Fos & & 28.4 & $\mathrm{Cd} 22$ & & 0.4 \\
\hline Adm & & 8.0 & Cxcl12 & & 0.2 & ${ }^{1}$ Foxm1 & & 13.9 & Hdac7a & & $0.5,4.3$ \\
\hline Adora2a & & 0.5 & Cxcl16 & & 0.3 & Gal & & 11.3 & Igh-1a & & 0.3 \\
\hline${ }^{1}$ Anxa1 & & 4.3 & Ddt & & 4.4 & ${ }^{1} \mathrm{Hgf}$ & & 0.4 & Il15 & $3^{\mathrm{a}}$ & 0.4 \\
\hline Apoa2 & & 2.9 & Dfy & & $0.4,8.5$ & Hmox2 & & 0.4 & $\mathrm{Il} 2$ & & $0.3,3.5$ \\
\hline Apol3 & & 2.6 & Dmd & & 0.3 & ${ }^{1}$ Hpse & & $0.3,6.3$ & Il4 & $3^{a, c}$ & $0.1,2.6$ \\
\hline App & & 6.4 & Ebi3 & & 0.2 & Icam1 & & 3.0 & $\mathrm{Il} 5$ & $3 c$ & 3.5 \\
\hline Blvra & & 3.5 & Ela2 & & $0.5,52.0$ & Ighe & & $0.2,2.5$ & $\mathrm{Il} 7$ & $3^{c}$ & 2.8 \\
\hline C1qr1 & 4 & 5.5 & F2 & 1 & 0.3 & Ikbkb & & 0.3 & Indo & & $0.4,2.3$ \\
\hline Cd163 & & 0.2 & F3 & 1 & $0.1,2.0$ & Ikbkg & & 0.4 & Odc1 & & 3.3 \\
\hline $\mathrm{Cd} 74$ & & 0.4 & Gif & & 0.1 & Il15 & $3^{\mathrm{b}}$ & 0.4 & Plp & & 0.1 \\
\hline Chst1 & & 0.0 & Gsk3b & & 0.4 & Il16 & & $0.4,3.1$ & Ppara & & 0.3 \\
\hline Chst2 & & 4.4 & Hrh1 & & $0.5,9.9$ & ${ }^{1} \mathrm{Il} 1 \mathrm{~B}$ & & 0.4 & Sele & $3^{\mathrm{a}}$ & 12.9 \\
\hline Col1a2 & & 3.0 & Hrh4 & & 7.5 & Il1f5 & & $0.4,2.8$ & Spp1 & $3^{c}$ & $0.5,2.7$ \\
\hline Col3a1 & & $0.3,6.5$ & ${ }^{1}$ Ifng & & 6.5 & Il1f8 & & 0.5 & c Cell differ & rentiation & \\
\hline Crbpb & & 3.1 & Igfbp4 & & 0.5 & Il1r1 & & 0.5 & $\mathrm{Il} 12 \mathrm{rb} 2$ & & 2.8 \\
\hline Esrra & & 0.2 & $\mathrm{Il} 17 \mathrm{f}$ & & 0.1 & Il1rn & & 16.3 & $\mathrm{Il} 4$ & $3^{a, b}$ & $0.1,2.6$ \\
\hline Fcgr1 & & 2.6 & Il6 & & $0.3,6.1$ & Il22ra2 & & 0.1 & $\mathrm{Il} 5$ & $3^{\mathrm{b}}$ & 3.5 \\
\hline Itgb2 & & 0.5 & I16r & & 3.0 & IL2ra & & $0.3,4.3$ & $\mathrm{Il} 7$ & $3^{\mathrm{b}}$ & 2.8 \\
\hline Klrg1 & & 0.4 & Ins1 & & 2.1 & $\mathrm{Il} 2 \mathrm{rg}$ & & $0.2,5.1$ & Spp1 & $3^{\mathrm{b}}$ & $0.5,2.7$ \\
\hline Lcn2 & & $0.5,257.2$ & Jak2 & & 6.5 & $\mathrm{Il} 4^{\circ}$ & $3^{\mathrm{b}, \mathrm{c}}$ & $0.1,2.6$ & Stat5a & & 0.2 \\
\hline Map2k3 & & 0.4 & Jun & & $1.0,6.9$ & Il5ra & & 7.0 & Stat $5 b$ & & 0.3 \\
\hline Mapk1 & & 2.7 & Lif & & $0.4,3.0$ & Itgam & 4 & 3.4 & Tslp & & $0.5,6.1$ \\
\hline $\mathrm{Mbp}$ & & 0.4 & Loc297568 & & 0.4 & Lama5 & & 3.8 & 4 Phagocyto & sis & \\
\hline Ms4a1 & $3^{\mathrm{a}}$ & 0.1 & Mapk8 & & $0.5,19.7$ & Lamc1 & & $0.4,2.5$ & Ager & $3^{\mathrm{a}}$ & 0.4 \\
\hline Ncf1 & & $0.2,3.7$ & ${ }^{1} \mathrm{Mmp} 9$ & & $0.5,9.5$ & Ltb4r & 1 & $0.5,8.7$ & C1qr1 & $2^{\mathrm{a}}$ & 5.5 \\
\hline Nfkbiz & & 6.6 & Nos3 & 1 & $0.3,2.1$ & Mbl2 & & 0.2 & Cybb & $3^{\mathrm{a}}$ & 2.5 \\
\hline Nostrin & & 8.0 & $\mathrm{P} 2 \mathrm{rx} 7$ & & $0.4,2.5$ & Mcpt6 & & 0.2 & Itgam & $3^{\mathrm{a}}$ & 3.4 \\
\hline Orm1 & & 2.8 & Pbef1 & & 8.1 & Mif & & 3.2 & Itih4 & & 0.3 \\
\hline Parg & & 4.8 & Pik3cd & & 0.3 & Mob & & 7.0 & Lyz & & $0.4,3.7$ \\
\hline Pla2g4b & & 2.0 & Plaur & & 13.9 & Ms4a1 & $2^{a}$ & 0.1 & Nox1 & & $0.3,8.6$ \\
\hline Psen2 & & 0.2 & Ppbp & & $0.1,2.1$ & Ms4a2 & & $0.4,5.3$ & Nox4 & & $0.1,3.0$ \\
\hline Ptger3 & 1 & 0.2 & Ptgs1 & & $0.7,3.4$ & Mug1 & & $0.1,3.5$ & & & \\
\hline Reg3a & & $0.1,64.0$ & Rgs16 & & $0.1,8.6$ & Myd88 & & 2.1 & & & \\
\hline Rela & $3^{\mathrm{a}}$ & 0.5 & Serpinb5 & & $0.5,12.1$ & Ncr3 & & 0.3 & & & \\
\hline
\end{tabular}

${ }^{1}$ Indicates the reported genes associated with liver regeneration; the letters " $a$ " and " $b$ " at the top right corner of the number " 2 " respectively indicate "Process of release" and "Cytokine" during the process of release cytokine, the letters " $a$ ", " $b$ " and " $c$ " at the top right corner of the number " 3 " respectively refer to "Cell activation", "Cell proliferation" and "Cell differentiation" in the process of cell activation, proliferation and differentiation. 

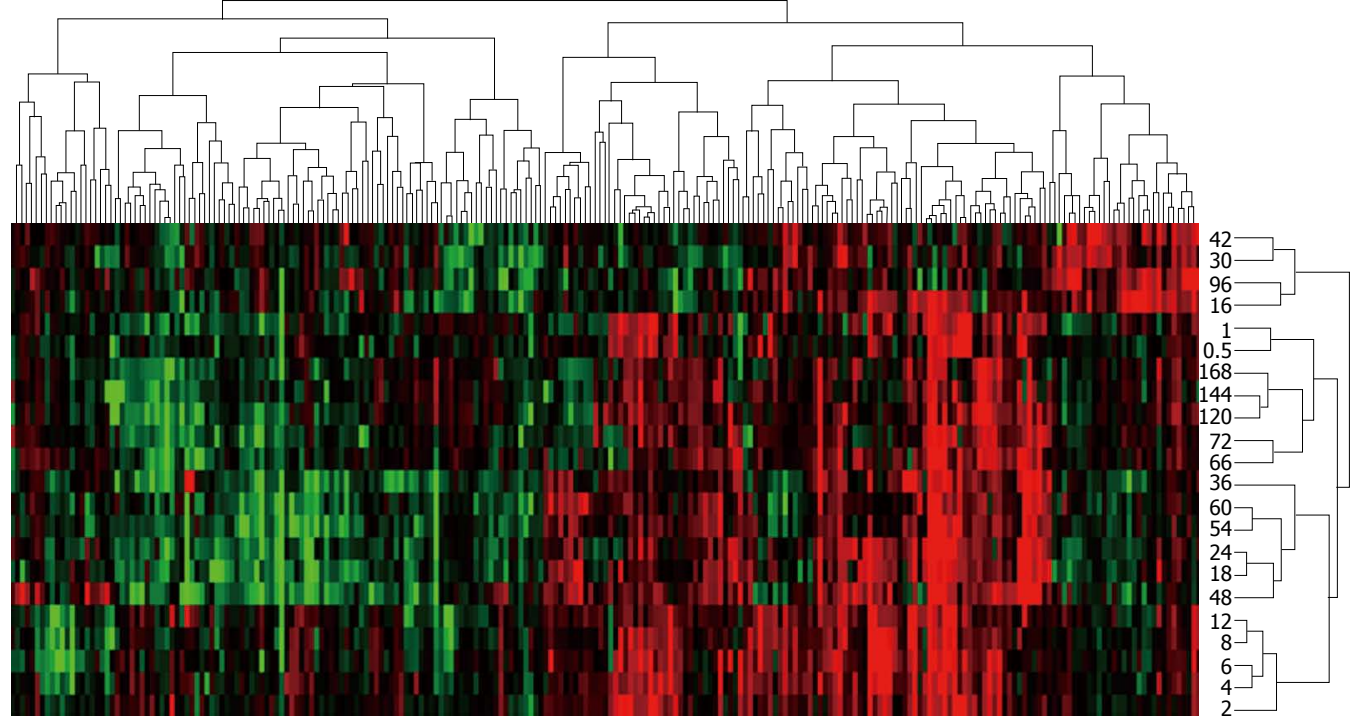

Figure 3 Expression similarity and time relevance clusters of 239 inflammatory responseassociated genes during liver regeneration. Detection data of Rat Genome 2302.0 array were analyzed by $\mathrm{H}$-clustering. Red represents up-regulated genes chiefly associated with promotion of inflammatory response; Green represents down-regulation ones mainly associated with suppression of inflammatory response; Black: No-sense in expression change. The upper and right trees respectively show expression similarity and time series clusters, by which the above genes were classified into 5 and 13 groups separately.

$168 \mathrm{~h}$ and the up- and down-regulated times were 81 and 25, 55 and 2, 118 and 28, 101 and 31, 93 and 42, 105 and 69, 64 and 44, 41 and 38, 66 and 46, 77 and 65, 68 and 39, 75 and 44, 31 and 21 respectively (Figure 3). The upregulated genes were chiefly ones promoting inflammatory response, and the down-regulated genes were mostly ones suppressing inflammatory response.

\section{Expression patterns of genes associated with inflammatory response during liver regeneration}

Two hundred and thirty-nine genes were categorized into 33 patterns, according to the changes in their expression. (1) up-regulation at one time point, i.e. 4, 6, 16, 18, 30, 48, 96, $120 \mathrm{~h}$ after partial hepatectomy (Figure 4A), 11 genes involved; (2) up at two time points, i.e. 6 and $66 \mathrm{~h}, 12$ and 60 h, 16 and 42 h, 16 and 96 h, 24 and 48 h, 30 and 42 h, 36 and 66 h, 48 and 120 h, 72 and 120 h (Figure 4B), 13 genes involved; (3) up at three time points (Figure 4C), 5 genes involved; (4) up at multiple time points (Figure 4D), 6 genes involved; (5) up at one time phase, i.e. 0.5-6 h, 0.5-8 h, 1-48 h, 6-12 h (Figure 4E), 4 genes involved; (6) up at two time phases, i.e. 16-24 h and 42-48 h (Figure 4E), 1 gene involved; (7) up at three time phases (Figure 4E), 1 gene involved; (8) up at multiple time phases (Figure 4E), 1 gene involved; (9) up at one time point/phase, i.e. 0.5 and 4-12 h, 18 and 48-60 h, 48 and 2-24 h, 54 and 6-24 h, 66 and 6-24 h, 96 and 1-24 h, 120 and 2-72 h, 120 and 0.5-8 h (Figure 4F), 8 genes involved; (10) up at one time point/ two phases (Figure 4G), 5 genes involved; (11) up at one time point/three phases (Figure 4G), 3 genes involved; (12) up at two time points/one phase (Figure 4H), 7 genes involved; (13) up at two time points/phases (Figure 4I), 6 genes involved; (14) up at two time points/three phases (Figure 4J), 8 genes involved; (15) up at three time points/ one phase (Figure 4K), 1 gene involved; (16) up at three time points/two phases (Figure 4K), 6 genes involved; (17) up at multiple time points/phases (Figure 4L), 6 genes involved; (18) down at one time point, i.e. 4, 6, 16, 18, 30, 36, 42, 48, 54, 60, 72, $168 \mathrm{~h}$ (Figure 4M, 4N), 28 genes involved; (19) down at two time points, i.e. 0.5 and $48 \mathrm{~h}$, 1 and 72 h, 16 and 42 h, 16 and 30 h, 18 and 54 h, 18 and
168 h, 30 and 42 h, 30 and 96 h, 42 and 66 h (Figure 4O ), 11 genes involved; (20) down at three time points (Figure 4O), 2 genes involved; (21) down at multiple time points (Figure 4O), 1 gene involved; (22) down at one phase i.e. 4-8 h, 4-6 h, 4-12 h, 6-12 h (Figure 4P), 4 genes involved; (23) down at two phases, i.e. 18-24 and 48-54 h (Figure 4P), 1 gene involved; (24) down at one time point/phase, i.e. 36 and 48-60 h, 48 and 12-30 h, 48 and 18-24 h, 54 and 18-24 h, 72 and 120-144 h (Figure 4Q), 5 genes involved; (25) down at one time point/two phases (Figure 4Q), 4 genes involved; (26) down at one time point/three phases (Figure 4Q), 2 genes involved; (27) down at two time points/one phase (Figure 4R), 6 genes involved; (28) down at two time points/phases (Figure 4R), 6 genes involved; (29) down at three time points/one phase (Figure 4S), 2 genes involved; (30) down at multiple time points/phases (Figure 4S), 5 genes involved; (31) predominantly up (Figure 4T and U), 25 genes involved; (32) predominantly down (Figure 4V), 14 genes involved; (33) similarly up/down (Figure 4W and $\mathrm{X}$ ), 31 genes involved.

\section{DISCUSSION}

Inflammatory response is a self-protection mechanism formed during the long evolution, closely bound up with higher animal survival. In the process, six proteins including leukotriene B4 receptor (LTB4R), are associated with vascular reactions, through enhancing vascular permeability $^{[21]}$. In addition, seven other proteins including platelet-activating factor receptor (PTAFR) have a role in increasing vasodilatation and permeability ${ }^{[22]}$. Four proteins including oxidized low density lipoprotein receptor 1 (OLDLR1) promote leukocytes and proteins to exude from vessels ${ }^{[23]}$. Four proteins including regenerating islet derived 3 gamma (REG3G) accelerate vasodilatation ${ }^{[24]}$. Four proteins including amine oxidase copper containing 3 (AOC3) restrain leucocytes to migrate to sites of inflammation ${ }^{[25]}$. The meaningful expression profiles of the genes encoding the above proteins were the same or similar at some points while different at others, indicating that they may co-regulate vascular reaction. Among them, 

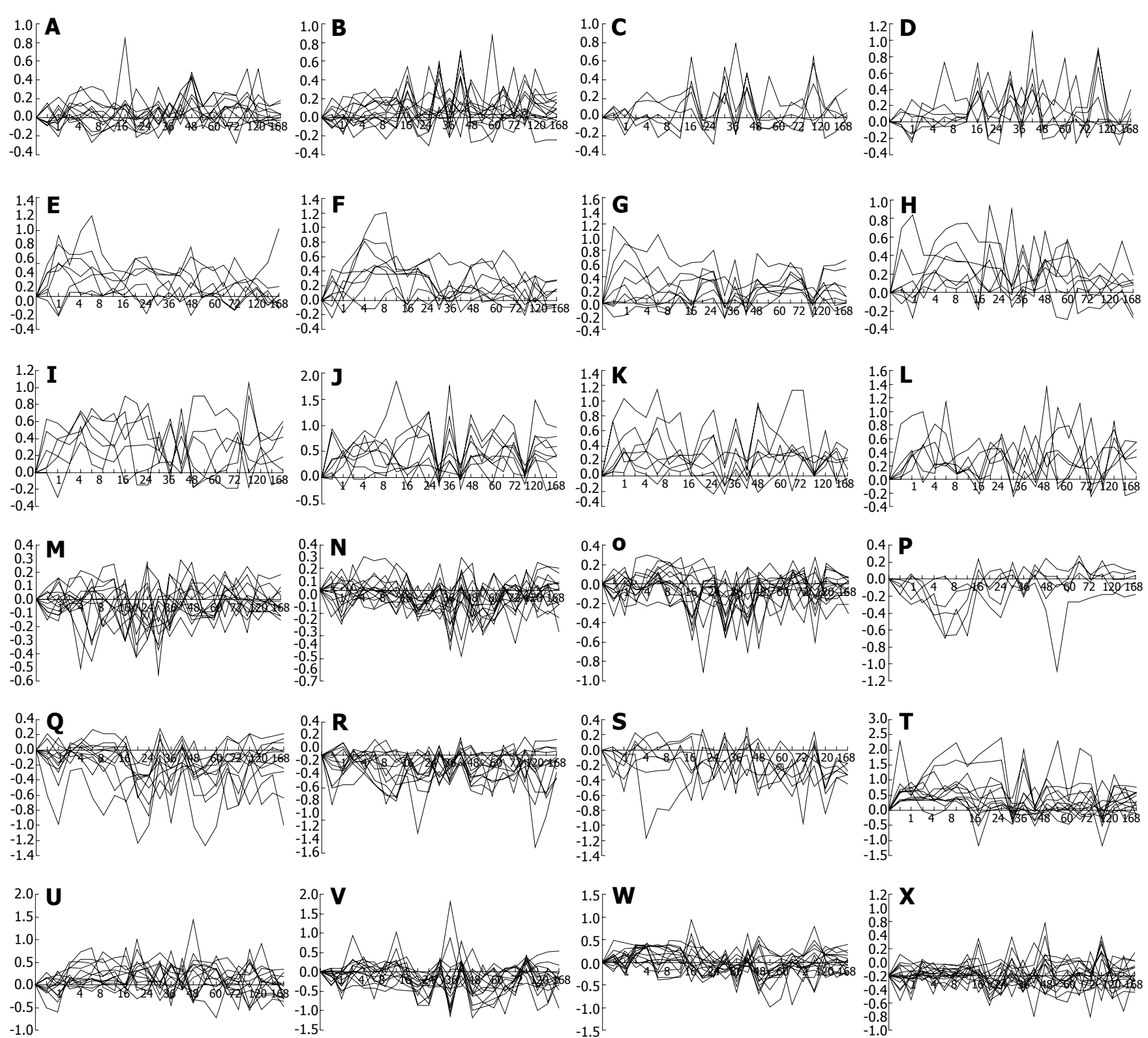

Figure 4 Thirty-three gene expression patterns of 239 inflammatory response-associated genes during liver regeneration. Expression patterns were obtained by the analysis of detection results of Rat Genome 2302.0 array with Microsoft Excel. A-L: 92 up-regulated genes; M-S: 77 down-regulated genes; T-X: 70 up/down-regulated genes. X-axis represents recovery time after partial hepatectomy $(\mathrm{h}) ; \mathrm{Y}$-axis shows logarithm ratio of the signal values of genes at each time point to control.

aoc3 was up-regulated at 36, 54 and $168 \mathrm{~h}$ after $\mathrm{PH}$, and reached a peak at $36 \mathrm{~h}$, which was 6.1 fold of control. ltb4r was up- at $6,18,36,48$ and $60 \mathrm{~h}$ after $\mathrm{PH}$, and reached a peak at $60 \mathrm{~h}$, which was 6 fold of control. oldlr 1 was up- at 2-6, 18-24 and 48-66 h after $\mathrm{PH}$, and reached a peak at 6 h, which was 6.5 fold of control. ptafr was up- at 16, 30, 42 and $96 \mathrm{~h}$ after $\mathrm{PH}$, and reached a peak at $96 \mathrm{~h}$, which was 7.1 fold of control. reg $3 g$ was up- at 12 and $36 \mathrm{~h}$ after $\mathrm{PH}$, and reached a peak at $36 \mathrm{~h}$, which was 7.5 fold of control. It is assumed that the above genes play a key role in vascular reaction during liver regeneration.

Ten proteins including lipocalin 2 (LCN2), associated with cytokine release, are activated by interleukins to promote inflammation ${ }^{[26]}$. Integrin beta 2 (ITGB2) stimulates leucocytes to secrete IL-12 $2^{[27]}$. Nine proteins including regenerating islet-derived 3 alpha (REG3A) accelerate cytokines synthesis ${ }^{[28]}$. Fourteen proteins including toll-like receptor 2 (TLR2) increase activation of macrophages ${ }^{[29]}$. Nine proteins including vacuolar protein sorting 45 (VPS45) stimulate the release of inflammatory factors, such as histamine, bradykinin ${ }^{[30]}$. The meaningful expression profiles of the genes encoding these proteins, being the same or similar at some points while different at others, indicate that they may co-regulate cytokine release. Among them, Icn2 was up-regulated at 0.5-24, 36, 48-72 and 120-168 h after partial hepatectomy, and reached a peak at $24 \mathrm{~h}$, which was 257 fold of control. reg $3 a$ was upat 12,36 and $96 \mathrm{~h}$ after $\mathrm{PH}$, and reached a peak at $36 \mathrm{~h}$, which was 64 fold of control. tlr2 was up- at 0.5-8, 18-66 and $120-168 \mathrm{~h}$ after $\mathrm{PH}$, and reached a peak at $168 \mathrm{~h}$, which was 10.6 fold of control. vps 45 was up- at 16, 30, 42 and $96 \mathrm{~h}$ after $\mathrm{PH}$, and reached a peak at $42 \mathrm{~h}$, which was 12.6 fold of control. It is suggested that the above genes play a key role in cytokine release during liver regeneration. 
Twelve proteins including chemokine $\mathrm{C}-\mathrm{C}$ motif ligand 7 (CCL7), associated with inflammatory response, accelerate $\mathrm{T}$ cell migration to sites of inflammation ${ }^{[31]}$. Nine proteins including plasminogen activator urokinase receptor (PLAUR) promote leukocyte adhesion ${ }^{[32]}$. Eight proteins including serine or cysteine peptidase inhibitor clade $\mathrm{E}$ member 1(SERPINE1) promote inflammatory cell migration ${ }^{[33]}$. Ten proteins including mitogenactivated protein kinase 8 (MAPK8) promote neutrophils, macrophages and $\mathrm{T}$ cells to ooze from blood vessel ${ }^{[34]}$. ATP-binding cassette sub-family B member 1 (ABCB1) enhances the transduction of inflammatory signaling ${ }^{[35]}$. Three proteins including alpha-2-macroglobulin (A2M) restrain the activities of various proteases including trypsin, thrombin and collagenase ${ }^{[36]}$. Twelve proteins including chemokine $\mathrm{C}-\mathrm{C}$ motif receptor 1 (CCR1) inhibit the activities of leukocyte and inflammatory protein (MIP)-1 by enhancing the chemotaxis of neutrophils, monocytes, lymphocytes and eosinophils ${ }^{[37]}$. The meaningful expression profiles of these genes showed the sameness or similarity at some points while exhibited difference at others, suggesting that they may regulate the cytokinemediated inflammation together. Among them, a2 $m$ was up- at $0.5-24,36$ and $48-54 \mathrm{~h}$, and reached a peak at $8 \mathrm{~h}$, which was 46.2 fold of control. This is generally consistent with the result reported by Scotte $e t a^{[38]}$. serpine 1 was upat 1-48 h, and reached a peak at $6 \mathrm{~h}$, which was 16.7 fold of control. This is in conformity with the result reported by Mueller et a ${ }^{[39]}$. $c c l 7$ was up- at 1-4, 12, 24, 48, 66 and 144-168 h, and reached a peak at $48 \mathrm{~h}$, which was 22.6 fold of control. ccr1 was up- at 8-36, 48 and $120 \mathrm{~h}$, and reached a peak at $48 \mathrm{~h}$, which was 27.9 fold of control. mapke 8 was up- at $0.5-24,48-60,72$ and $144 \mathrm{~h}$, having a peak at $4 \mathrm{~h}$, which was 12 fold of control. plaur was up- at 1, 6, 18-24, 48, 72 and $120 \mathrm{~h}$, and had the highest abundance of 13.9 fold at $6 \mathrm{~h}$. It indicates that these genes play a key role in inflammation during liver regeneration.

Among the proteins associated with the inflammatory cell activation, connective tissue growth factor (CTGF) enhances macrophage activity via M-CSF (macrophage colony-stimulating factor ${ }^{[40]}$. Eight proteins including cysteine aspartate-specific protease 8 (CASP8) lead inflammatory response by accelerating neutrophil apoptosis ${ }^{[41]}$. Ten proteins including $\mathrm{v}$-fos FBJ murine osteosarcoma viral oncogene homolog (FOS) accelerate inflammatory response by activating MAPK ${ }^{[42]}$. Six proteins including forkhead box M1 (FOXM1) induce inflammatory response when they are over expressed ${ }^{[43]}$. Seven proteins including pancreatitis-associated protein (PAP) inhibit inflammatory response by suppressing the activity of $\mathrm{NF}_{\kappa} \mathrm{B}^{[44]}$. Six proteins including fatty acid binding protein 4 (FABP4) inhibit inflammatory response by reducing the activities of $N F \kappa B$ and $I \kappa B$ of macrophages ${ }^{[45]}$. Eight proteins including interleukin 1 receptor antagonist (IL1RN) decrease inflammatory response by inhibiting the activities of IL1A and IL1B ${ }^{[46]}$. Four proteins including galanin (GAL) suppress inflammatory response by inhibiting proliferation of thymus cells and macrophages ${ }^{[4]]}$. The meaningful expression profiles of the genes encoding the proteins mentioned above showed the sameness or similarity at some point while exhibited difference at others, implying that they may co-regulate the activity of inflammatory cell. Among them, ctof was up- at $0.5-8,18-24,36,54$ and $72 \mathrm{~h}$ after $\mathrm{PH}$, and reached a peak at $6 \mathrm{~h}$, which was 13.9 fold of control. This is consistent with the results reported by Pi $e t a^{[48]}$. foxm 1 was up- at 1 , 18-24, 36, 48-72 and $120 \mathrm{~h}$ after $\mathrm{PH}$, and reached a peak at $66 \mathrm{~h}$, which was 13.9 fold of control. This is in line with the results reported by Wang $e a^{[43]}$. casp 8 was up- at 1, 18-24, 36, 48-72 and 120-168 h, and reached a peak at $48 \mathrm{~h}$, which was 10.6 fold of control. fabp 4 was up- at 4, $12-24,36,48-72$ and $120-168 \mathrm{~h}$, and reached a peak at $120 \mathrm{~h}$, which was 29.9 fold of control. fos was up- at 0.5-30, 42-48 and $120 \mathrm{~h}$ after $\mathrm{PH}$, and reached a peak at $0.5 \mathrm{~h}$, which was 28.4 fold of control. gal was up- at 1-16, 30, 42 and 96-120 $\mathrm{h}$ after $\mathrm{PH}$, and reached a peak at $96 \mathrm{~h}$, which was 11.3 fold of control. ill $\mathrm{rn}$ was up- at 2-24 and $48 \mathrm{~h}$ after $\mathrm{PH}$, and reached a peak at $8 \mathrm{~h}$, which was 16.3 fold of control. pap was up- at 1-24, 36, 48-54, 66 and 120-144 h after $\mathrm{PH}$, and reached a peak at $12 \mathrm{~h}$, which was 68.6 fold of control. It is assumed that these genes play vital roles in inflammatory cell activation during LR.

Nine proteins including B-cell CLL/lymphoma 6 (BCL6), associated with inflammatory cell proliferation, promote the proliferation of $\mathrm{T}$ cells and $\mathrm{B}$ cells ${ }^{[49]}$. Five proteins including selectin E (SELE) promote recruitment of white blood cells to inflammation sites by activating neutrophils ${ }^{[50]}$. Three proteins including cluster of differentiation 276 (CD276) induced by LPS inhibit $\mathrm{T}$ cell proliferation ${ }^{[51]}$. The meaningful expression profiles of the genes encoding these proteins showed the sameness or similarity at some points while difference at others, indicating that they may modulate inflammatory cell proliferation together. Remarkably, sele showed up-regulation at 0.5-2, 16-24, 36, 54-66 and 96-120 $\mathrm{h}$ with the highest abundance of 12.9 fold of control at $66 \mathrm{~h}$ after PH. bcl6 was up- at $0.5-12,24,48-54,72$ and $120-168 \mathrm{~h}$, and reached a peak at $0.5 \mathrm{~h}$, which was 8.6 times higher than the control. It is supposed that they are important in inflammatory cell proliferation during liver regeneration.

Interleukin 12 receptor beta 2 (IL12RB2), associated with inflammatory cells differentiation, promotes Th1 cells differentiation ${ }^{[52]}$. Three proteins including thymic stromal lymphopoietin (TSLP) facilitate the differentiation of $\mathrm{CD} 4(+) \mathrm{T}$ cells to $\mathrm{Th} 2$ cells $^{[53]}$. The meaningful expression profiles of the genes encoding these proteins exhibited the sameness or similarity at some points while difference at others, indicating that they may co-regulate inflammatory cell differentiation. Remarkably, tslp displayed up-regulation at 18-24, 36, 48-60, 72 and 120-144 $\mathrm{h}$ with the highest abundance of 6.1 fold at $18 \mathrm{~h}$ after $\mathrm{PH}$, indicating that it is essential to inflammatory cell differentiation during liver regeneration.

Five proteins including complement component 1 q subcomponent receptor 1 (C1QR1), associated with inflammation elimination, can clear dead cells by promoting monocytes, neutrophils and epithelial cells to secrete inflammatory factors ${ }^{[54]}$. Lysozyme (LYZ) promotes bacterialepicyte dissolution ${ }^{[5]}$. NADPH oxidase 1, 4 (NOX1, NOX4) accelerate cell aging by catalyzing production of active oxygen ${ }^{[5]}$. The meaningful expression changes of these genes displaying sameness or similarity at some 
points while difference at others indicate that they may coregulate subsidence of inflammation. Especially, $y z$ was up-regulated at 1-4, 48 and $96 \mathrm{~h}$, and reached a peak at 48 $\mathrm{h}$, which was 3.7 times higher than the control. nox 1 was up- at $0.5-8,18$ and $120 \mathrm{~h}$, and had a peak expression at $2 \mathrm{~h}$, which was 8.6 times higher than the control. $c 1$ gr1 was upat $0.5-12,24,36,60-72$ and $120-168 \mathrm{~h}$, reaching a peak at $8 \mathrm{~h}$, which was 5.5-fold of control. It is supposed that the three genes are of importance in eliminating inflammation during liver regeneration.

In conclusion, the expression changes of the inflammatory response-associated genes after partial hepatectomy in rats have been investigated with highthroughput gene expression analysis. It is preliminarily confirmed that inflammatory response is enhanced during liver regeneration; that Rat Genome 2302.0 array is a useful tool for analysis of the inflammatory response at the transcriptional level. However, the process of DNA $\rightarrow$ $\mathrm{mRNA} \rightarrow$ protein $\rightarrow$ function is influenced by many factors including protein interaction. Therefore, further analyses of our results using techniques, such as Northern blotting, protein chip, RNA interference, protein-interaction are needed.

\section{REFERENCES}

1 Terui K, Ozaki M. The role of STAT3 in liver regeneration. Drugs Today (Barc) 2005; 41: 461-469

2 Ogoke BA. The management of the atlanto-occipital and atlanto-axial joint pain. Pain Physician 2000; 3: 289-293

3 Higgins GM, Anderson R M. Experimental pathology of the liver: restoration of the liver of the white rat following partial surgical removal. J Arch Pathol 1931; 12: 186-222

4 Michalopoulos GK, DeFrances M. Liver regeneration. Adv Biochem Eng Biotechnol 2005; 93: 101-134

5 Yamayoshi $Y$, Watanabe T, Tanabe M, Hoshino K, Matsumoto K, Morikawa Y, Shimadzu M, Kitajima M, Tanigawara Y. Novel application of ProteinChip technology exploring acute rejection markers of rat small bowel transplantation. Transplantation 2006; 82: 320-326

6 Nanobashvili KV, Okropiridze TV, Kapanadze RV. Cytological issues of Curiosin's influence on the inflammatory processes in parodontal tissues. Georgian Med News 2006; 135: 57-60

7 Hirsch IB. Inpatient diabetes: review of data from the cardiac care unit. Endocr Pract 2006; 12 Suppl 3: 27-34

8 Taub R. Liver regeneration: from myth to mechanism. Nat Rev Mol Cell Biol 2004; 5: 836-847

9 Fausto N, Campbell JS, Riehle KJ. Liver regeneration. Hepatology 2006; 43: S45-S53

10 Xu CS, Zhao LF, Yang KJ, Zhang JB. The origination and action of the hepatic stems cells. ShiYan ShengWu XueBao 2004; 37: $72-77$

11 Sonesson B, Rosengren E, Hansson AS, Hansson C. UVB-induced inflammation gives increased d-dopachrome tautomerase activity in blister fluid which correlates with macrophage migration inhibitory factor. Exp Dermatol 2003; 12: 278-282

12 Dransfeld O, Gehrmann T, Köhrer K, Kircheis G, Holneicher C, Häussinger D, Wettstein M. Oligonucleotide microarray analysis of differential transporter regulation in the regenerating rat liver. Liver Int 2005; 25: 1243-1258

13 Li L, Roden J, Shapiro BE, Wold BJ, Bhatia S, Forman SJ, Bhatia R. Reproducibility, fidelity, and discriminant validity of mRNA amplification for microarray analysis from primary hematopoietic cells. J Mol Diagn 2005; 7: 48-56

14 Hood L. Leroy Hood expounds the principles, practice and future of systems biology. Drug Discov Today 2003; 8: 436-438

15 Yue H, Eastman PS, Wang BB, Minor J, Doctolero MH, Nuttall RL, Stack R, Becker JW, Montgomery JR, Vainer M, Johnston
R. An evaluation of the performance of cDNA microarrays for detecting changes in global mRNA expression. Nucleic Acids Res 2001; 29: E41-E41

16 Knepp JH, Geahr MA, Forman MS, Valsamakis A. Comparison of automated and manual nucleic acid extraction methods for detection of enterovirus RNA. J Clin Microbiol 2003; 41: 3532-3536

17 Nuyts S, Van Mellaert L, Lambin P, Anné J. Efficient isolation of total RNA from Clostridium without DNA contamination. Microbiol Methods 2001; 44: 235-238

18 Arkin A, Ross J, McAdams HH. Stochastic kinetic analysis of developmental pathway bifurcation in phage lambda-infected Escherichia coli cells. Genetics 1998; 149: 1633-1648

19 Eisen MB, Spellman PT, Brown PO, Botstein D. Cluster analysis and display of genome-wide expression patterns. Proc Natl Acad Sci USA 1998; 95: 14863-14868

20 Werner T. Cluster analysis and promoter modelling as bioinformatics tools for the identification of target genes from expression array data. Pharmacogenomics 2001; 2: 25-36

21 Toda A, Yokomizo T, Masuda K, Nakao A, Izumi T, Shimizu T. Cloning and characterization of rat leukotriene $\mathrm{B}(4)$ receptor. Biochem Biophys Res Commun 1999; 262: 806-812

22 Negrão-Corrêa D, Souza DG, Pinho V, Barsante MM, Souza $\mathrm{AL}$, Teixeira MM. Platelet-activating factor receptor deficiency delays elimination of adult worms but reduces fecundity in Strongyloides venezuelensis-infected mice. Infect Immun 2004; 72: 1135-1142

23 Honjo M, Nakamura K, Yamashiro K, Kiryu J, Tanihara $\mathrm{H}$, McEvoy LM, Honda Y, Butcher EC, Masaki T, Sawamura T. Lectin-like oxidized LDL receptor-1 is a cell-adhesion molecule involved in endotoxin-induced inflammation. Proc Natl Acad Sci USA 2003; 100: 1274-1279

24 Keilbaugh SA, Shin ME, Banchereau RF, McVay LD, Boyko $\mathrm{N}$, Artis D, Cebra JJ, Wu GD. Activation of RegIIIbeta/gamma and interferon gamma expression in the intestinal tract of SCID mice: an innate response to bacterial colonisation of the gut. Gut 2005; 54: 623-629

25 Merinen M, Irjala H, Salmi M, Jaakkola I, Hänninen A, Jalkanen S. Vascular adhesion protein-1 is involved in both acute and chronic inflammation in the mouse. Am J Pathol 2005; 166: 793-800

26 Cowland JB, Sørensen OE, Sehested M, Borregaard N. Neutrophil gelatinase-associated lipocalin is up-regulated in human epithelial cells by IL-1 beta, but not by TNF-alpha. J Immunol 2003; 171: 6630-6639

27 Emoto M, Miyamoto M, Emoto Y, Yoshizawa I, Brinkmann V, van Rooijen N, Kaufmann SH. Highly biased type 1 immune responses in mice deficient in LFA-1 in Listeria monocytogenes infection are caused by elevated IL-12 production by granulocytes. J Immunol 2003; 171: 3970-3976

28 Drognitz O, Michel P, Koczan D, Neeff H, Mikami Y, Obermaier R, Thiesen HJ, Hopt UT, Loebler M. Characterization of ischemia/reperfusion-induced gene expression in experimental pancreas transplantation. Transplantation 2006; 81: 1428-1434

29 Arbour NC, Lorenz E, Schutte BC, Zabner J, Kline JN, Jones M, Frees K, Watt JL, Schwartz DA. TLR4 mutations are associated with endotoxin hyporesponsiveness in humans. Nat Genet 2000; 25: 187-191

30 Rajasekariah P, Eyre HJ, Stanley KK, Walls RS, Sutherland GR. Molecular cloning and characterization of a cDNA encoding the human leucocyte vacuolar protein sorting (h1Vps45). Int J Biochem Cell Biol 1999; 31: 683-694

31 Michalec L, Choudhury BK, Postlethwait E, Wild JS, Alam R, Lett-Brown M, Sur S. CCL7 and CXCL10 orchestrate oxidative stress-induced neutrophilic lung inflammation. J Immunol 2002; 168: 846-852

32 Shushakova N, Eden G, Dangers M, Menne J, Gueler F, Luft FC, Haller H, Dumler I. The urokinase/urokinase receptor system mediates the IgG immune complex-induced inflammation in lung. J Immunol 2005; 175: 4060-4068

33 Aso Y, Wakabayashi S, Yamamoto R, Matsutomo R, Takebayashi K, Inukai T. Metabolic syndrome accompanied by 
hypercholesterolemia is strongly associated with proinflammatory state and impairment of fibrinolysis in patients with type 2 diabetes: synergistic effects of plasminogen activator inhibitor-1 and thrombin-activatable fibrinolysis inhibitor. Diabetes Care 2005; 28: 2211-2216

34 Stambe C, Atkins RC, Hill PA, Nikolic-Paterson DJ. Activation and cellular localization of the p38 and JNK MAPK pathways in rat crescentic glomerulonephritis. Kidney Int 2003; 64: 2121-2132

35 Jansen G, Scheper RJ, Dijkmans BA. Multidrug resistance proteins in rheumatoid arthritis, role in disease-modifying antirheumatic drug efficacy and inflammatory processes: an overview. Scand I Rheumatol 2003; 32: 325-336

36 Milosavljevic TS, Petrovic MV, Cvetkovic ID, Grigorov II. DNA binding activity of C/EBPbeta and C/EBPdelta for the rat alpha2-macroglobulin gene promoter is regulated in an acute-phase dependent manner. Biochemistry (Mosc) 2002; 67: 918-926

37 Gao JL, Wynn TA, Chang Y, Lee EJ, Broxmeyer HE, Cooper S, Tiffany HL, Westphal H, Kwon-Chung J, Murphy PM. Impaired host defense, hematopoiesis, granulomatous inflammation and type 1-type 2 cytokine balance in mice lacking CC chemokine receptor 1. J Exp Med 1997; 185: 1959-1968

38 Scotté $\mathbf{M}$, Masson S, Lyoumi S, Hiron M, Ténière P, Lebreton JP, Daveau M. Cytokine gene expression in liver following minor or major hepatectomy in rat. Cytokine 1997; 9: 859-867

39 Mueller L, Broering DC, Meyer J, Vashist Y, Goettsche J, Wilms C, Rogiers $X$. The induction of the immediate-earlygenes Egr-1, PAI-1 and PRL-1 during liver regeneration in surgical models is related to increased portal flow. J Hepatol 2002; 37: 606-612

40 Nakao K, Kubota S, Doi H, Eguchi T, Oka M, Fujisawa T, Nishida T, Takigawa M. Collaborative action of M-CSF and CTGF/CCN2 in articular chondrocytes: possible regenerative roles in articular cartilage metabolism. Bone 2005; 36: 884-892

41 Alvarado-Kristensson M, Melander F, Leandersson K, Rönnstrand L, Wernstedt C, Andersson T. p38-MAPK signals survival by phosphorylation of caspase- 8 and caspase- 3 in human neutrophils. J Exp Med 2004; 199: 449-458

42 Mahimainathan L, Ghosh-Choudhury N, Venkatesan BA, Danda RS, Choudhury GG. EGF stimulates mesangial cell mitogenesis via PI3-kinase-mediated MAPK-dependent and AKT kinase-independent manner: involvement of c-fos and p27Kip1. Am J Physiol Renal Physiol 2005; 289: F72-F82

43 Wang X, Bhattacharyya D, Dennewitz MB, Kalinichenko VV, Zhou Y, Lepe R, Costa RH. Rapid hepatocyte nuclear translocation of the Forkhead Box M1B (FoxM1B) transcription factor caused a transient increase in size of regenerating transgenic hepatocytes. Gene Expr 2003; 11: 149-162

44 Vasseur S, Folch-Puy E, Hlouschek V, Garcia S, Fiedler F,
Lerch MM, Dagorn JC, Closa D, Iovanna JL. p8 improves pancreatic response to acute pancreatitis by enhancing the expression of the anti-inflammatory protein pancreatitis-associated protein I. J Biol Chem 2004; 279: 7199-7207

45 Makowski L, Brittingham KC, Reynolds JM, Suttles J, Hotamisligil GS. The fatty acid-binding protein, aP2, coordinates macrophage cholesterol trafficking and inflammatory activity. Macrophage expression of aP2 impacts peroxisome proliferator-activated receptor gamma and IkappaB kinase activities. J Biol Chem 2005; 280: 12888-12895

46 Pastor IJ, Laso FJ, Romero A, González-Sarmiento R. Interleukin-1 gene cluster polymorphisms and alcoholism in Spanish men. Alcohol Alcohol 2005; 40: 181-186

47 Qinyang W, Hultenby K, Adlan E, Lindgren JU. Galanin in adjuvant arthritis in the rat. J Rheumatol 2004; 31: 302-307

48 Pi L, Oh SH, Shupe T, Petersen BE. Role of connective tissue growth factor in oval cell response during liver regeneration after 2-AAF/PHx in rats. Gastroenterology 2005; 128: 2077-2088

49 Dogan A, Burke JS, Goteri G, Stitson RN, Wotherspoon AC, Isaacson PG. Micronodular T-cell/histiocyte-rich large B-cell lymphoma of the spleen: histology, immunophenotype, and differential diagnosis. Am J Surg Pathol 2003; 27: 903-911

50 Bevilacqua MP, Stengelin S, Gimbrone MA, Seed B. Endothelial leukocyte adhesion molecule 1: an inducible receptor for neutrophils related to complement regulatory proteins and lectins. Science 1989; 243: 1160-1165

51 Prasad DV, Nguyen T, Li Z, Yang Y, Duong J, Wang Y, Dong C. Murine B7-H3 is a negative regulator of T cells. J Immunol 2004; 173: 2500-2506

52 Akahoshi M, Ishihara M, Remus N, Uno K, Miyake K, Hirota T, Nakashima K, Matsuda A, Kanda M, Enomoto T, Ohno S, Nakashima H, Casanova JL, Hopkin JM, Tamari M, Mao XQ, Shirakawa T. Association between IFNA genotype and the risk of sarcoidosis. Hum Genet 2004; 114: 503-509

53 Ito T, Wang YH, Duramad O, Hori T, Delespesse GJ, Watanabe N, Qin FX, Yao Z, Cao W, Liu YJ. TSLP-activated dendritic cells induce an inflammatory $\mathrm{T}$ helper type 2 cell response through OX40 ligand. J Exp Med 2005; 202: 1213-1223

54 Bohlson SS, Silva R, Fonseca MI, Tenner AJ. CD93 is rapidly shed from the surface of human myeloid cells and the soluble form is detected in human plasma. J Immunol 2005; 175: 1239-1247

55 Kaur G, Sarwar Alam M, Athar M. Nimbidin suppresses functions of macrophages and neutrophils: relevance to its antiinflammatory mechanisms. Phytother Res 2004; 18: 419-424

56 Plesková M, Beck KF, Behrens MH, Huwiler A, Fichtlscherer B, Wingerter O, Brandes RP, Mülsch A, Pfeilschifter J. Nitric oxide down-regulates the expression of the catalytic NADPH oxidase subunit Nox1 in rat renal mesangial cells. FASEB J 2006; 20: 139-141

S- Editor Liu Y L- Editor Zhu LH E- Editor Bi L 